\title{
Evaluation of Quality Early Childhood Education Program Services Using CIPP Model
}

\author{
Utsman $^{1}$, Fakhruddin $^{2}$, and Bagus Kisworo ${ }^{3}$ \\ \{utsman@mail.unnes.ac.id ${ }^{1}, \underline{\text { fakhruddin@mail.unnes.ac.id }}{ }^{2}$, \\ bagus.kisworo@mail.unnes.ac.id $\left.{ }^{3}\right\}$ \\ Department of Non-formal Education, Universitas Negeri Semarang, A2 Building Sekaran Campus \\ Gunungpati, Semarang, Indonesia ${ }^{123}$
}

\begin{abstract}
The purpose of this evaluation study is to analyzing the effect of context, input evaluation, the process of the quality of the ECE program in Semarang city. To find this out, quantitative research was conducted with the exposure facto research approach. This evaluative research will be conducted ECE in Semarang city with a population of 553 ECE educators, sample in the study are 120 ECE educators. Data collection techniques used is observation and questionnaire. The analysis technique used in this study uses Structural Equitation Modeling software, AMOS 24.0. The results of the study show: context evaluation, input evaluation, and process evaluation has a positive and significant effect on the quality of ECE services in Semarang city. So the decreasing quality of the process in ECE services will have difficulties in improving the quality of ECE services, and context, input, and process evaluation together have a significant effect on the quality of ECE service in Semarang city.
\end{abstract}

Keywords: Evaluation, Quality, Early Childhood Education.

\section{Introduction}

Early childhood is a golden age period because the growth and development of children takes place very quickly and briefly, also sensitive to the environment. From conception to early childhood is a period where risks and opportunities for child development [1]. This period is usually characterized by rapid changes in physical, cognitive, social and emotional development. This period is a time to lay the first foundation in developing physical (motoric), intellectual, emotional, social, language, art, and spiritual moral potential [2]. Therefore, from an early age children must be given proper and adequate education. Early childhood education services in Indonesia have developed rapidly but nevertheless not all early childhood children can be served by the government or the private sector [3].

Recognizing the need for early childhood education services, the government has lately strived to accelerate early childhood education program services, both through formal and informal education. Formal education for early childhood ECE is usually given to children aged 5-6 years while non-formal educatin is given to children aged 3-4 years. The effort was made so that most early childhood receive reasonable education services to develop children's potential as early as possible, because early age is the age of "gold" for child development. 
The implications of the law are: First, encourage the government and the private sector to provide adequate education services and facilities since early childhood, although early childhood education is not an education that must be implemented, and not a prerequisite for entering primary education. Second, ECE service programs are not only provided formally but also provided informally and non-formally. Third, ECE service programs are educational needs that must be served as early as possible to develop human resources, because the quality of Indonesia's human resources by many is considered still low. This is caused by the low quality of education in various types and levels of education [4]. Indicators of the low quality of education include: Indonesia's Human Development Index (HDI) from year to year is still low $[5]$.

According to Aqib [6], one of the factors causing low quality of education is that attention to early childhood education is still very minimal. For this reason, one way to improve the quality of human resources is to improve the quality of early childhood education because early age is the most important and fundamental initial period throughout the span of growth and development of human life (golden ages).

Considering the importance of children's education at an early age, the government's attention in developing ECE is getting bigger. In addition, the community also showed concern for the problem of early childhood education by providing various services in accordance with the conditions and capabilities of each who obtained new ECE services around $53.7 \%$ due to the limited existing ECE institutions. Hiryanto, et al. [7] regarding the mapping of the quality achievement level of ECE programs in DIY Province shows that there is an age group that is not in accordance with the guidelines because of limited facilities, infrastructure and educators. There are still educators who have not received training. The ratio of the number of educators and students is not ideal. Another finding is the limited educational toys (APE), limited facilities and infrastructure that are not balanced with the number of students as a result the children scramble to use toys.

Hermawati [8] in Daycare center Beringharjo Yogyakarta found two weaknesses of the input variable. They are the teaching qualifications of teachers and caregivers that were not relevant to the field of duty. In the process variable, the problem is not yet measurable mentoring activities by caregivers. In terms of the process, ECE has been taught to read, write, and count because according to the educator, if it is not taught, the institution does not get students. Play activities are also not optimal because game tools are usually limited. The results of the development achievements have never been evaluated by the education office so that it is not known for certain. Likewise, information on children at home has never been reported by parents to the teacher. This is important as a form of cooperation between family and community with the institution in monitoring the development of children.

In order for quality early childhood education services ECE, in accordance with existing standards, it is necessary to evaluate the ECE service program. Quality education services are services that are continuously evaluated and the results are followed up appropriately [9]. Mardapi [10] stated that such an increase in the quality of education can be achieved through improving the quality of learning and through improving the evaluation system. The overall evaluation model that will be applied to this research is an evaluation of a program that uses the Context, Input, Process, Product (CIPP) evaluation model developed [11].

A context evaluation's main objectives are to describe the context for the intended service; identify intended beneficiaries and assess their needs to identify problems or barriers to meeting the needs; identify the area of assets and funding opportunities that could be used to address the targeted needs; and assess the clarity and appropriateness of programs, instructional, or other service goals [11]. 
The second step evaluates inputs, what needs to be done on input evaluation is analyzing problems related to the use of available resources, recognizing system capabilities, alternative program strategies, design procedures for implementation strategies, financing, and scheduling [11]. In evaluating inputs, it is necessary to consider the strategies needed to complete the program objectives. This can be in the form of human resources, funds and facilities. If human resources and facilities are not in accordance with standards and needs, then non-formal ECE services are of less quality. Efforts to improve quality are needed by professional human resources (HR). Professional HR must have education and expertise and have good motivation, competence and work commitment.

Input evaluation is also associated with the relevance, practicality, financing, effectiveness, and superior alternatives of a program. The input evaluation component includes: 1) human resources, 2) supporting facilities and equipment, 3) funds or budget, and 4) various procedures and rules needed.

The third steps, models are the evaluation of the process. Evaluation is designed and applied in practice or guiding in the implementation of activities. Including identifying damage to implementation procedures both managing events and activities [11]. Process evaluation has a goal to detect in procedural design or its implementation during implementation stage, to provide information for programmed decisions, and to maintain a record of the procedure as it occurs" [12].

Basically the CIPP model of the process evaluation is directed at how far the activities carried out in the program which has been carried out according to the plan. Is the program implemented according to schedule? Will the program implementer be able to handle activities during the program and the possibility if the program continues? Are the facilities and infrastructure provided to be fully utilized? What obstacles and support do occur in the implementation of the program?

Fourth step is product evaluation. This evaluation is to see the results that have been achieved and what is still being done. At this stage what is done is to determine the level of the program objectives that have been achieved. In this type of evaluation the target measures are developed and managed. Existing data can be used by program administrators to make decisions about continuing and modifying the program. Product evaluation aims to measure, interpret, and assess program achievements. More specifically, to assess the success of the program [13].

The hypotheses formulated in this study are. 1) There is the influence of the ACE context on the quality of ECE program in Semarang city. 2) There is an influence of ECE input on the quality of the ECE program in Semarang city. 3) There is the influence of the process on the quality of ECE program in Semarang city. 4) There is the influence of context, input, and ECE processes on the quality of ECE program in Semarang.

\section{Method}

This research uses a quantitative approach with exposure facto. Respondents in this study were ECE educators for children aged 3-4 years in Semarang City with a population of 553 ECE educators. The sampling technique used in this study uses the theory of Isac and Michael, samples taken $20 \%$ of the population so that the total of samples used in the study are $120 \mathrm{ECE}$ educators. Determining the number of samples with the formula Isaac and Michel makes it easy to determine the number of samples with an error rate of $1 \%, 5 \%$, and $10 \%$. With the estimation method using Maximum Likehood (ML) a minimum sample of 100 and a maximum of 200 is 
required [14]. Data collection techniques used is observation and questionnaire. Before the instrument was applied in the field, it was first tested for validity and reliability. The results of the validity test for the variable, input, process, and product instruments are declared valid. Also, all variable instruments in context, input, process, and product are declared reliable. The data analysis technique in this study 1) uses descriptive statistical analysis. This analysis is used to analyze data by describing the collected data as it is without intending to make conclusions that apply to the general or generalizations (Sugiyono, 2015). In this study to find out the results of CIPP evaluation of the quality of ECE services in Semarang City using the descriptive percentage analysis method, 2) Analysis of Structural Equation Modeling (SEM) is used to analyze the data obtained because of the models arranged there is a relationship between a number of variables can be estimated simultaneously. SEM testing in this study used statistical software, AMOS 24.

\section{Result and Discussion}

Before it is done using the Analysis of Structural Question Modeling (SEM), the first classical assumption test is performed. The first Assumption test uses data normalization test using critical ratio skewness. The data is said to be normal if the critical ratio skewness is below the value of \pm 2.58 at the 0.05 level of significance. The data can be concluded to have a normal distribution if the value of the critical ratio skewness is below the absolute price of 2.58 . The data normality test results are shown in table 1 as follows.

Table 1. Normality Test for Univariate and Multivariate Data.

\begin{tabular}{lrrrrrr}
\hline Variable & Min & max & skew & c.r. & kurtosis & c.r. \\
\hline Context & 25.000 & 47.000 & -.077 & -.343 & -.671 & -1.499 \\
Process & 63.000 & 109.000 & -.247 & -1.103 & .360 & .805 \\
Input & 34.000 & 59.000 & -.034 & -.151 & -.463 & -1.035 \\
Product & 136.000 & 246.000 & -.090 & -.404 & -.813 & -1.817 \\
Multivariate & & & & & -1.888 & -1.493 \\
\hline
\end{tabular}

The Maximum Likelihood (ML) estimation technique is more efficient and unbiased if the assumption of multivariate normality is fulfilled with the number of Critical Ratio (CR) \pm 2.58 [15]. Normal data must be multivariate and univariate normal. On the contrary, if the entire normal data is univariate, it is not a guarantee that it will be normal multivariate which is outside the range \pm 2.58 . These results indicate that the research data used has met the normality of data prerequisites or in other words that the data in this study have been normally distributed. Next, a molycolinierity test was carried out to see whether the data contained molticulinierity in a variable combination model. Indicator is molticulinieritas if the determination value of the covariance matrix is really small or close to zero. Based on data processing, the value of determination of the sample covariance matrix is: Determinant of sample covariance matrix $=$ 51741923,673 . It can be concluded that the determinant of sample covariance matrix is very far from zero. So it was concluded that the research data used did not occur with the problem of molyculinierity. The data has unique characteristics that look very different from observations.

The next stage is an evaluation of the outliers. Outliers are observations or others and appear in extreme forms, both for a single variable and for combination variables. The outliers can be evaluated, namely the analysis of univariate outliers. Testing for the presence or absence of 
univariate outliers is done by analyzing the $\mathrm{Z}$ score from the research data used. If there is a $\mathrm{Z}$ score in the range of -3 to 3 , it will be categorized as an outlier. Univariate outliers testing using the SPSS program is carried out on each variable construct. The results of processing data for testing can be seen in the following table.

Table 2. Z-score Evaluation

\begin{tabular}{|c|c|c|c|c|c|c|c|}
\hline \multicolumn{8}{|c|}{ Descriptive Statistics } \\
\hline & $\mathrm{N}$ & Range & Minimum & Maximum & Mean & $\begin{array}{c}\text { Std. } \\
\text { Deviation }\end{array}$ & Variance \\
\hline Zscore(Context) & 120 & 4.88270 & -2.55972 & 2.32298 & $\begin{array}{r}.000000 \\
0\end{array}$ & 1.00000000 & 1.000 \\
\hline Zscore(Input) & 120 & 5.77648 & -2.25555 & 2.52093 & $\begin{array}{r}.000000 \\
0\end{array}$ & 1.00000000 & 1.000 \\
\hline Zscore(Process) & 120 & 4.19243 & -2.16071 & 2.03172 & $\begin{array}{r}.000000 \\
0\end{array}$ & 1.00000000 & 1.000 \\
\hline Zscore(Product) & 120 & 4.47839 & -2.12873 & 2.34966 & $\begin{array}{r}.000000 \\
0\end{array}$ & 1.00000000 & 1.000 \\
\hline Zscore(Quality) & 120 & 3.84859 & -2.18553 & 1.66306 & $\begin{array}{r}.000000 \\
0\end{array}$ & 1.00000000 & 1.000 \\
\hline Valid N (listwise) & 120 & & & & & & \\
\hline
\end{tabular}

Based on the computerized results above, there is no $\mathrm{z}$ score that is higher than \pm 3.0 with an average value of 0 and a standard of devotion of 1 , because it can be concluded that all indicators have small variance values. Other than univariate outlier's evaluation, evaluation for multivariate outliers is necessary because even though outlier data at the multivariate level can be known from the Mahalanobis Distance through the AMOS program. The Mahalanobis Distance test is calculated using the chi-square value at the free degree of 15 at $p<0.001$ which if consulted on the chi-square table value is 24.99. The results of the analysis of the presence or absence of multivariate outliers indicate that the maximum Mahalanobis distance is 19.75 $<24.99$. This shows that there are no multivariate outliers.

After the classic assumption test, an analysis of the results of data processing on the whole or full SEM model was carried out by testing the goodness of fit and statistical tests. The following is the presentation of the results of the overall analysis or the full SEM model in the form of image.

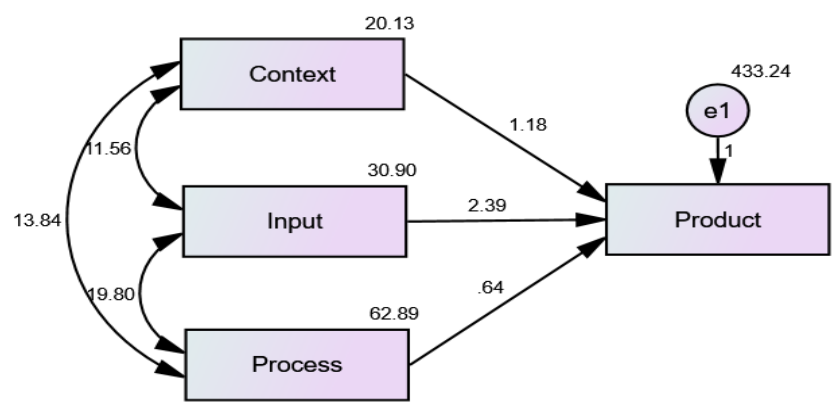

Figure 1. Structural Equation Modeling ECE Quality Services Evaluation with the CIPP Model 
Tests for the whole or full SEM model using the criteria in SEM testing include Chi-Square, Probability, CMIN / DF, GFI, AGFI, TLI, CFI and RMSEA according to the expected value conditions. Referring to the opinion of Solimun [16] states that based on the parsimony principle, if there are one or two fit criteria the model has been fulfilled, the model has been declared fit. The results of testing the feasibility of the model or the goodness of fit SEM are shown in the following table.

Table 3. Feasibility Test Results Model Analysis of Structural Equation Modeling)

\begin{tabular}{lccc}
\hline Goodness of Fit Index & Cut-off Value & Results & $\begin{array}{c}\text { Model } \\
\text { Evaluation }\end{array}$ \\
\hline$X^{2}$ Chi- Square Statistik & df, $\alpha \leq 0,05$ & 0,0 & $\begin{array}{c}\text { Good } \\
\text { Probability }\end{array}$ \\
CMIN/DF & $\leq 0,05$ & - & Marginal \\
GFI & $\geq 0,00$ & - & Marginal \\
AGFI & $\geq 0,90$ & 1,000 & Good \\
TLI & $\geq 0,90$ & - & Marginal \\
CFI & $\geq 0,90$ & 1,000 & Marginal \\
RMSEA & $\leq 0,08$ & 0,427 & Good \\
\hline
\end{tabular}

Based on table 3 above, it can be stated that the regression model used is acceptable. At the level of the chi-square value, 0.0 indicates a structural equation model is in the good category.

\subsection{Hypothesis Testing}

Hypothesis testing is the next step that must be done after testing the Structural Equation Modeling (SEM) to fulfill the hypothesis that has been proposed in this study. Testing of all hypotheses is done by looking at the Critical Ratio (C.R) value of a quality relationship from the results of SEM processing as presented in the following table.

Table 4. Testing the Hypotheses of Each Variable

\begin{tabular}{llrrrrr}
\hline & & Estimate & S.E. & C.R. & P & Label \\
\hline Product <--- & Context & 1.182 & .493 & 2.398 & .016 & \\
Product <--- & Input & 2.393 & .410 & 5.833 & $* * *$ & \\
Product <--- & Process & .635 & .277 & 2.297 & .022 & \\
\hline
\end{tabular}

Here is an effect of Context Evaluation on Service (Product) Quality ECE Programs. Estimation parameters in testing the effect of evaluating the context on the service quality of ECE programs show a C.R value of 2,398 with a probability of $<0.05$. So it can be concluded that context evaluation has a significant effect on the quality of ECE program. Here is an effect of Input Evaluation on Service (Product) Quality of ECE Programs. Estimation parameters in testing the effect of input evaluation on the service quality of ECE programs show a C.R value of 5.822 with a probability of $<0.05$. So it can be concluded that input evaluation has a significant effect on the quality of ECE program. Here is an effect of Process Evaluation on Service (Product) Quality of ECE Programs. Estimation parameters in testing the effect of process evaluation on service quality of ECE programs show a C.R value of 2,297 with a probability of $<0.05$. So it can be concluded that process evaluation has a significant effect on the quality of ECE programs. Here is an effect of Evaluation of Context, Input, and Process Together on Service (Product) Quality of ECE Programs. The equation for testing the effect of CIPP evaluation on the quality of ECE services, Quality of service (product) ECE $=0.186$ 
Context evaluation +0.467 Evaluation of input +0.177 Evaluation process. This shows that there is an influence that evaluates context, input, and process simultaneously towards the quality of ECE products.

\subsection{Inter-Variable Influence Analysis}

Influence analysis is done to determine the strength between the constructs of overall influence or total. The direct effect is the coefficient of the overall coefficient line with one end arrows. The overall or total effect is the effect of various relationships [17]. The presentation of the effects of influences between variables is presented in the following image.

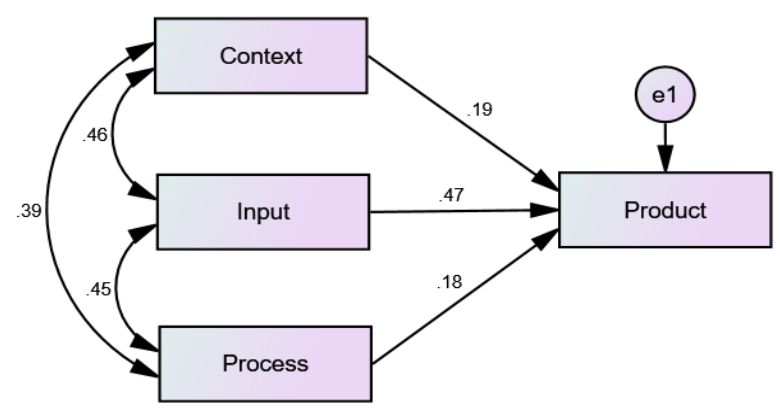

Figure 2. Inter-Variable on the Path Diagram

Based on the picture above, some estimates between variables are exogenous variables towards endogenous variables. The value of the total influence can be seen in the table presented below.

Table 5. Standardized Total Effects

\begin{tabular}{rrrr}
\hline & Context & Process & Input \\
\hline Product & .186 & .177 & .467 \\
\hline
\end{tabular}

Based on the table above, it is known that the total effect of the exogenous variable on the highest variable quality of (product) service and the strongest influence is the input variable of 0.467 , while the variable with the lowest influence is the process variable which is equal to 0.177 . Based on the estimation results in image 2, the effect of context, input, process, on the quality of ECE products is as follows.

Based on the results of data processing carried out using AMOS 24 program assistance, shows the results of the hypothesis that the evaluation of context, input, and process influences the quality of ECE services in Semarang city. Overall the results of hypothesis testing are presented in the following table.

Table 6. Inter-Variable Effect Testing

\begin{tabular}{|c|c|}
\hline Inter-Variable Effect & Total Effect \\
\hline Context Evaluation $\rightarrow$ Quality (product) of ECE & 0,186 \\
\hline Input Evaluation $\rightarrow$ Quality (product) of ECE & 0,467 \\
\hline Process Evaluation $\rightarrow$ Quality (product) of ECE & 0,177 \\
\hline
\end{tabular}

\subsection{Discussion}


Context evaluation has a significant influence on the quality of ECE program services. The influence is supported by ten indicators of context variables. The ten indicators include: the feasibility of ECE in the midst of society, the demands of the community for the needs of ECE, hopes of the community for ECE, fulfillment of community needs for ECE programs that are not meeting the expectations of the surrounding community, existing value systems support the existence of ECE, the priority of ECE programs that are the desire of the community, social problems that arise due to ECE, economic problems of people who use vECE, and the tendency of the surrounding community to not use ECE programs. After a descriptive analysis of the ten indicators above, the majority are in the high category.

Aspects evaluated in the context component were the juridical documents possessed by ECE institutions as a formal basis for ECE implementation including the Minister of National Education Regulation No. 58 of 2009 concerning ECE standards, documents on school establishment, procedures for conducting ECE [18]. This is also expressed by Derya \& Bulent [19], stating that decision makers at the input stage are used to set targets and priorities and monitor how the program targets according to the needs and problems specified.

Input evaluation has a positive and significant influence on the quality of services in the ECE program. The influence is supported by fifteen input variable indicators. From the fifteen indicators include: building feasibility for ECE learning, adequacy of classrooms for ECE learning, adequacy of space for ECE administration activities, adequacy of space or land for ECE children living, adequacy of educational toys for ECE seen from the type, adequacy of educational toys not seen from the number compared to children who use, the adequacy of learning media used in ECE, the adequacy of operational funds for ECE activities, the adequacy of the number of child counselors in ECE activities, the adequacy of the minimum education level for ECE supervisors, the adequacy of teaching materials used in ECE, motivation of counselors in ECE learning, pleasant environment for children, a safe atmosphere for ECE learning, a shady environment in the learning environment. After descriptive analysis of fifteen indicators above the majority are in the high category.

One of the evaluations of inputs is facilities evaluation, because facilities are one of the aspects that play an important role in ECE service programs. The evaluation results obtained are facilities that have a positive effect on ECE service programs [20]. In addition to the facets of facilities, there are several other aspects that need to be evaluated on the input component including students, educators, education staff, program content, facilities and infrastructure, management, financing [18]. The purpose of input evaluation is to consider all available options, taking into account the effectiveness of the facility or the feasibility of the proposed approach to clearly identify optimal strategies to meet the needs of students and the community [21].

Evaluation of the process in this study, carried out by the research team related to the feasibility of building for ECE learning, the adequacy of classrooms for ECE learning, adequate space for ECE administration activities, adequate space or land for ECE children, the adequacy of educational toys for ECE views, the adequacy of educational toys not seen from the number compared to children who use it, the adequacy of learning media used in ECE, the adequacy of operational funds for ECE activities, the adequacy of the number of child counselors in ECE activities, the adequacy of minimum education level for ECE supervisors (D2), adequacy of teaching materials which is used in ECE, motivation for mentors in ECE learning, pleasant environment for children, safe environment for ECE learning, a shady environment in the learning environment.

From the above indicators after a descriptive analysis, the results show that the majority of these indicators are in the high category. And this can be concluded that evaluation of inputs supported by the fifteen indicators above has a positive and significant effect on the quality of ECE program services.

Kasrani [18], states that the process evaluation refers to several aspects, including learning planning, implementation of learning, and assessment of learning. Process evaluation focuses on the course of the program and the learning process [22]. Implementation is the phase where input is used effectively to 
achieve the desired goals, objectives, and objectives of the product. Evaluators assess the process to understand how schools work and which processes are responsible for working better and maintaining the quality of education. In this phase, implementation decisions are taken.

\section{Conclusions}

Based on the results and discussion, which has been described previously, it can be concluded that evaluation of context has a positive and significant effect on the quality of ECE services (products) in Semarang city. So that it can be interpreted that the better the context in the implementation of ECE includes the analysis and identification of program implementation needs, it will improve the quality of (product) in the ECE services. Evaluation of inputs has a positive and significant effect on the quality of ECE services (products) in Semarang city. So it can be interpreted that the better the quality of inputs in ECE service will improve the quality of (product) in the ECE services. Process evaluation has a positive and significant effect on the quality of ECE services (products) in Semarang city. So it can be interpreted that the increasing quality of processes in ECE services will improve the quality of (product in the ECE services. Context, input, and process evaluation together influence the quality of (products) services in the ECE services in Semarang City.

Based on the research conclusions above, it is necessary to suggest several things including the following. To ECE educators, it is recommended to implement the process of ECE programs services by paying attention to the context and program inputs so that the results can achieve the efficiency and effectiveness of the programs services. For researchers or other parties who have an interest in evaluating the quality of ECE services using CIPP, researchers should make reference in applying evaluation in a wider scope, both from the subject and the object.

Acknowledgment. The author would like to thank to the Dean of the Faculty of Education, Universitas Negeri Semarang, who has helped in financing the realization of this research. Hopefully the results of this study will benefit all parties, Thank you. 


\section{References}

[1] Martani, W., 2012. Metode Stimulasi dan Perkembangan Emosi Anak Usia Dini. Jurnal Psikologi. 39 (1).

[2] Widhianawati, N., 2011. Pengaruh Pembelajaran Gerak dan Lagu dalam Meningkatkan Kecerdasan Musikal dan Kecerdasan Kinestetik Anak Usia Dini. Jurnal Penelitian Pendidikan. Edisi khusus (2) Agustus.

[3] Abdulhak, Ishak. (2012). Kebijakan Pendidikan anak usia dini, sekolah dasar dan pendidikan luar sekolah. Makalah disajikan dalam Seminar Kebijakan Pendidikan, di Badan Penelitian dan Pengembangan Departemen Pendidikan Jakarta. Nasional.

[4] Hadith Abdul, B. Nurhayati 2010. Educational Quality Management, Alfabeta, Bandung.

[5] Janawi. (2011). Kompetensi guru: Citra guru professional. Bandung: Alfabeta.

[6] Aqib, Zaenal. (2011). Pedoman teknis penyelenggaraan PAUD (Pendidikan anak usia dini). Bandung: Nuansa Aulia.

[7] Hiryanto, dkk. (2004). Pemetaan tingkat pencapaian mutu program pendidikan anak usia dini (PAUD) di Provinsi DIY. (Laporan penelitian, tidak diterbitkan). Yogyakarta: Lembaga penelitian UNY.

[8] Hermawati, Istiana. (2007). Evaluasi program pendidikan anak usia dini (PAUD) bagi anak dari keluarga miskin di tempat penitipan anak (TPA) Beringharjo Yogyakarta. Departemen Sosial RI: Balai Besar Penelitian dan Pengembangan Pelayanan Keasejahteraan Sosial (B2P3KS) Yogyakarta.

[9] Nugraha, Ali. (2010). Evaluasi pembelajaran untuk anak usia dini. Jakarta: Universitas Pendidikan Indonesia.

[10] Mardapi, Djemari. (2012). Pengukuran, penilaian,dan evaluasi pendidikan. Yogyakarta: Nuha\ Medika.

[11] Stufflebeam, D. L. et. al. (2000). Evaluation Models Viewpoints On Educational and Human Services Evaluation. Second Edition. New York: Luwer Academic Publishers.

[12] Worthen, B. (1990). Program evaluation. H. Walberg \& G. Haertel (Eds.), The international encyclopedia of educational evaluation (pp. 42-47). Toronto, ON: Pergammon Press.

[13] Mahmudi, I. (2011). CIPP: Suatu Model Evaluasi Program Pendidikan. At-Ta'dib, 6(1).

[14] Ghozali, Imam. (2008). Apikasi Analisis Multivariate dengan SPSS. Semarang: Badan Penerbit Universitas Diponegoro.

[15] Ghozali, Imam. (2013). Model Persamaan Struktural: Konsep dan Aplikasi dengan Program Amos 19.0. Cetakan Keempat. Semarang: Badan Penerbit Universitas Diponegoro.

[16] Solimun. (2002). Multivariate Analysis Structural Equation Modelling (SEM) Lisrel dan Amos. Jakarta: Indeks.

[17] Ferdinand, A, 2012. Structural Equation Modeling dalam penelitian Manajemen. Semarang: Badan Penerbit Universitas Diponegoro.

[18] Kasrani. 2016. Evaluasi Program Pendidikan Anak Usia Dini (PAUD). Jurnal Manajemen Pendidikan. 25 (2) : 233-243.

[19] Derya, K., \& Bulent, A. (2016). "Application of context input process and product model in curriculum evaluation: Case study of a call centre". Educational Research and Reviews, 11(17), pp.1659-1669. https://doi.org/10.5897/ERR2016.2911.

[20] Gunartha, I. W., Kartowagiran, B., \& Suardiman, S. P. (2014). Pengembangan model evaluasi program layanan pendidikan anak usia dini (PAUD). Jurnal Penelitian dan Evaluasi Pendidikan, 18(1), 30-43. https://doi.org/10.21831/pep.v18i1.2122.

[21] Powell, B., \& Conrad, E. (2015). "Utilizing the CIPP Model as a Means to Develop an Integrated Service-Learning Component in a University Health Course". Journal of Health Education Teaching, 6 (1), pp.21-32.

[22] Aziz, S. (2013). "Implementation of CIPP Model for Quality Evaluation at School Level : A Case Study". International Journal of Educational Management, 5(1), pp.189-206. http://dx.doi.org/10.22555/joeed.v5i1.1553. 